\title{
ROAD SAFETY INSPECTION AS A TOOL FOR ROAD SAFETY MANAGEMENT - THE POLISH EXPERIENCE
}

\author{
INSPEKCJA DROGOWA JAKO NARZĘDZIE \\ ZARZĄDZANIA BEZPIECZEŃSTWEM RUCHU \\ DROGOWEGO - DOŚWIADCZENIA POLSKIE
}

\section{Marcin Budzyński, Kazimierz Jamroz, Wojciech Kustra}

Politechnika Gdańska

\begin{abstract}
In Poland, road inspections were implemented in June 2014 on all national roads. Previous traffic surveys mainly looked at the technical condition of roads, signs and markings; other safety issues were overlooked. The main problem of the inspections is that the qualitative assessment is subjective which affects the classification of the sources of hazard on the road. The paper presents an analysis of the variability of the qualitative assessments of road defects when they are assessed by different teams of inspectors. On this basis, guidelines were developed for the classification of risks based on the relationship between sources of road hazard and the personal and economic losses involved in road accidents. These relationships are quantified using mathematical models to simulate the effect of hazard variability on the consequences of selected road accident causes on sections of the road network.
\end{abstract}

Keywords: road safety inspection, defects criteria, road safety models

Streszczenie: W Polsce inspekcje drogowe wdrożono do realizacji w czerwcu 2014 roku na wszystkich drogach krajowych. Głównym problemem, jaki występuje podczas wykonywanych inspekcji jest subiektywna jakościowa ocena inspektorów, która wplywa na klasyfikację źródet zagrożeń na drogach. $W$ referacie przedstawiono analize zmienności ocen jakościowych defektów na drodze, klasyfikowanych przez różne zespoty inspektorów. Na tej podstawie wypracowano zatożenia do klasyfikacji zagrożeń $w$ oparciu o zależności pomiędzy źródtami zagrożenia w ruchu drogowym, a stratami osobowymi i ekonomicznymi wypadków drogowych. Zależności te skwantyfikowano za pomoca modeli matematycznych umożliwiajacych symulowanie wplywu zmienności wybranego zbioru źródet zagrożenia na wybrane skutki wypadków drogowych na odcinkach sieci dróg.

Stowa kluczowe: inspekcja brd, kryteria defektów, modele brd 
Road safety inspection as a tool for road safety management - the polish experience Inspekcja drogowa jako narzędzie zarzadzania bezpieczeństwem ruchu drogowego...

ROAD SAFETY INSPECTION AS A TOOL FOR ROAD SAFETY MANAGEMENT - THE POLISH EXPERIENCE

\section{Introduction}

Poland continues to be one of the European Union's worst performing countries for road deaths. In 2015 there were 2,938 people killed on Polish roads with 39,800 people injured. While the priorities set out in national and regional road safety programmes help to systematically reduce Poland's road deaths, the results are far from what is expected.

Despite the transformation, Poland's road network is still behind on safety standards. Yet the lack of standards is hardly ever quoted as the cause of road accidents. Because there are no safety standards, road networks are defective. The defects pose a direct risk to road users and cause them to make mistakes. The defects must be identified and eliminated and the existing road network must be brought to the right safety standards. Defects are identified during road inspections which EU member countries are required to conduct under Directive 2008/96/CE [1] on road safety infrastructure management. The Directive identifies four main areas of action:

- road safety impact assessment (road safety assessment),

- road safety audit,

- ranking of high accident concentration sections (section ranking) and network safety ranking (network ranking),

- road safety inspection.

Commissioned by the General Directorate for National Roads and Motorways (GDDKiA) in 2013, the Gdansk University of Technology and the Krakow University of Technology developed the "Road Safety Inspection Instructions". The document is part of the implementation of the Directive and GDDKiA Director's road safety inspection regulations [2]. Two years into the implementation process in 2015 the Instructions were revised. This was to increase the effectiveness of the inspections, post-inspection reports and primarily the postinspection measures.

\section{Experience of other countries}

In many countries inspections of existing road networks are designed mainly to identify hazards and classify them. Once identified, hazards should be assigned to a risk class. Inspection should be seen as an interdisciplinary assessment covering all spheres of knowledge related to road safety. 
As well as the technical aspects of road infrastructure and vehicles, inspection must use the knowledge of road user behaviour and the physiological and psychological aspects of how the "man - road - vehicle - environment" system operates [3], [4].

Road inspection guidelines are developed and implemented not only by individual countries. EuroRap and PIARC are two organisations that have drafted the rules for conducting road safety inspections. EuroRAP is the European Road Assessment Programme [5] and an international not for profit association. PIARC is the World Road Association which brings together the road administrations of more than 120 countries [6].

While the procedures developed by both organisations are generally in line with those developed by the particular countries, they do differ in terms of their focus. Hazards are assessed by assessing the real safety level of a road section. A road safety inspection conducted on-site assesses the probability of becoming involved in a fatality or serious injury road accident. How strong the probability is depends on the standards which the road meets after planning, designing, building and traffic management.

\section{Background and procedures of Poland's road safety inspection}

Road safety inspection is part of road safety management based on risk management [7] and part of measures and preventative steps taken by road authorities. The purpose of road inspection is to identify hazards and sources of hazards on the road network and as a consequence, implement effective treatment to improve road user safety and road network standards.

Road network inspections are divided into three types: general (regular drives on inspected roads), detailed (on-site visits with observations of road user behaviour and checks of e.g. sight distance) and special (at night-time, in road works zones). The results of inspection can be used to update technical requirements or design guidelines and to help with selecting the right treatment. Fig. 1 shows a diagram of the inspection procedure.

Once identified, the defects should be assessed and assigned to three hazard classes: class A - low, class B - medium, class C - high. There are risk classes assigned to defect classes: high - unacceptable - class C hazard, medium conditionally acceptable (acceptable provided that specific treatment is applied) class B hazards, low - acceptable, class A hazards. The responses to the risks identified vary depending on the risk classes: immediate response, response spread over time - using immediate temporary solutions and responses to take place over time. The decisions should be taken based on inspector assessment (using their knowledge and experience) and objective measures of hazards. 
Road safety inspection as a tool for road safety management - the polish experience Inspekcja drogowa jako narzędzie zarzadzania bezpieczeństwem ruchu drogowego...

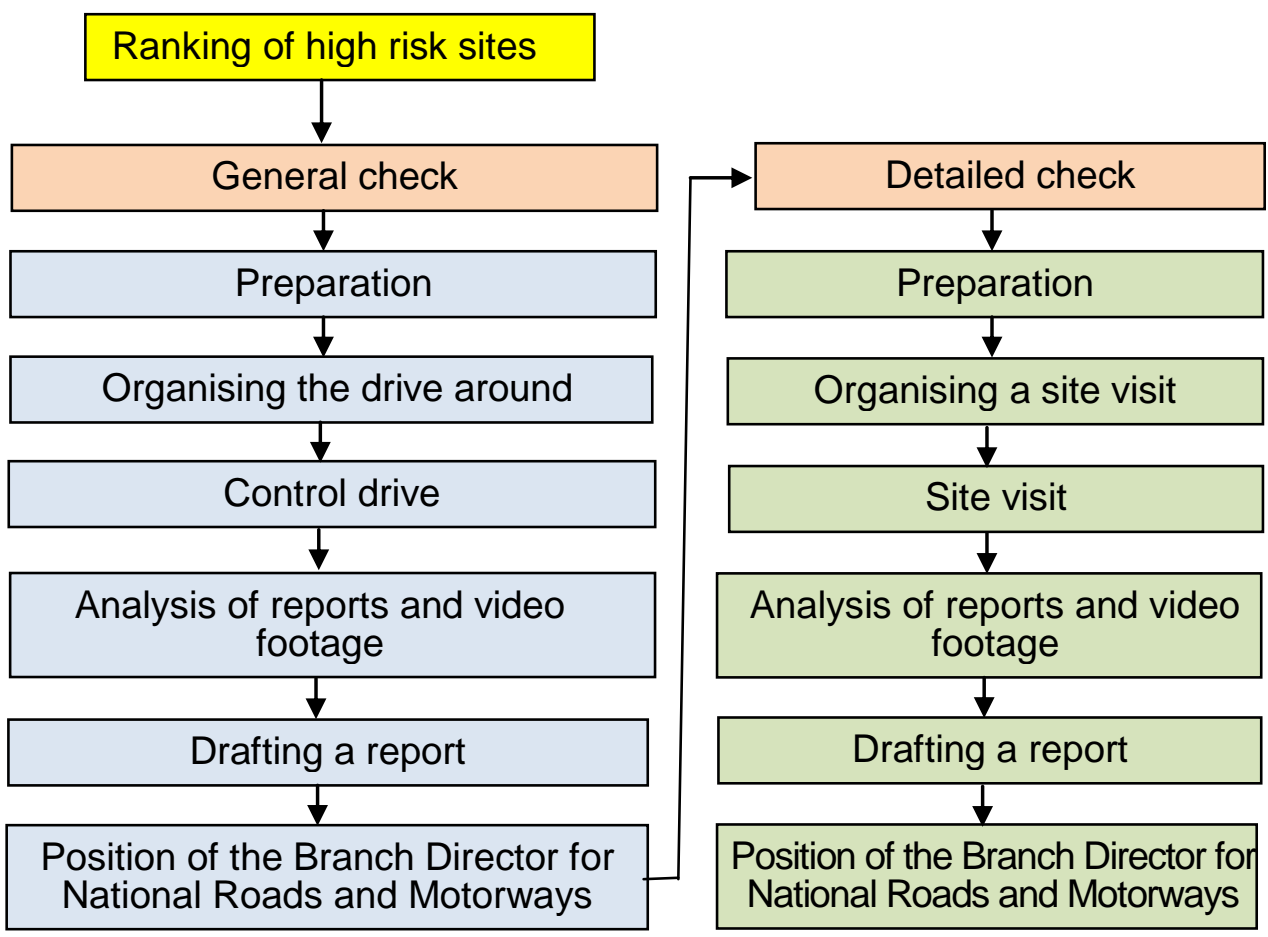

Fig. 1 Diagram of road safety check procedure on a road network

\section{Examples of hazard identification and classification and selected remedial measures}

The main criteria for classifying defects identified in an inspection are as follows:

- speed limit - set in the general regulations or local speed limits and real speed (if it exceeds the speed limit significantly this may be the consequence of a wrong cross-section)

- type of area (urban built-up, built-up - small towns, built-up on city outskirts, non-built-up),

- type of cross-section (cross-section 1x2 + wide hard shoulders outside urban areas are a potential class $\mathrm{C}$, similarly $1 \times 4$ cross-sections in built-up areas, $2 \times 2$ or $2 \times 3$ potentially mean much higher speeds than allowed - class $\mathrm{C}$ in the case of unsignalised at-grade pedestrian crossings),

Fig. 2 shows examples of class A hazards - a lamppost on the pavement (a), no link between the pedestrian crossing and pavement (b). Fig. 3 presents examples of class B hazards - no bus bay and poor condition of shoulder (a), no kerbed refuge for the pedestrian crossing (b). It should be emphasized that (a) the lack of proper pedestrian access to the bus stop and no proper refuge within the pedestrian crossing are potential class $C$ hazards. Fig. 4 shows examples of class $C$ hazards wrong barrier termination (a), junction geometry, the shape of the slip road (b). 

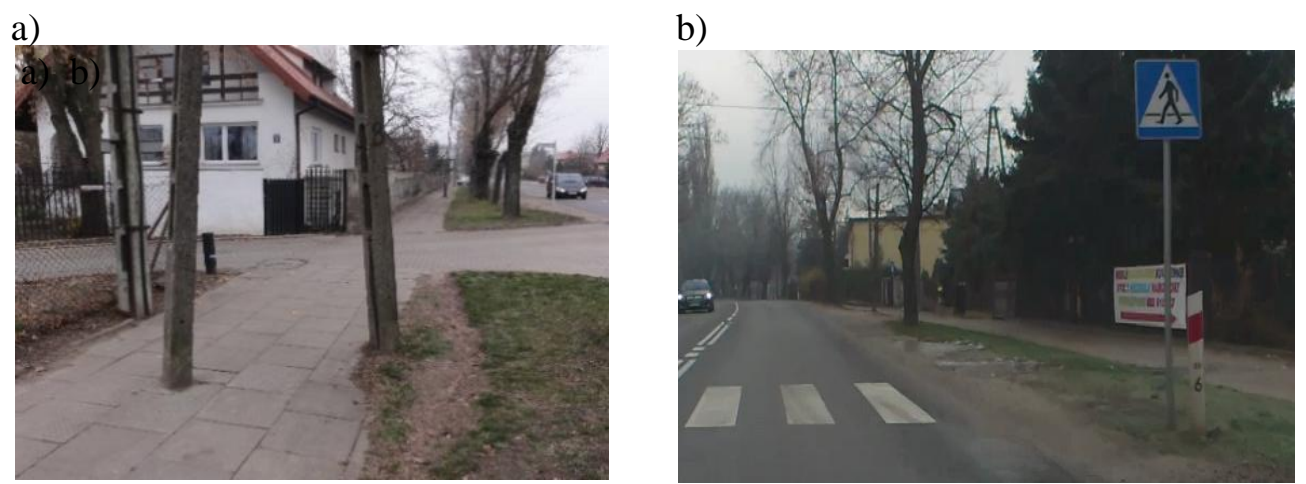

Fig. 2 Class A hazards

a)

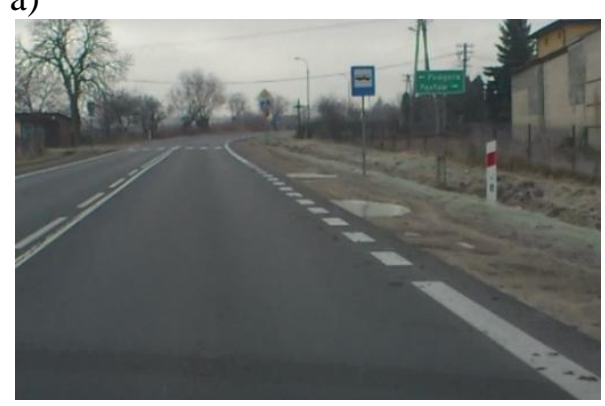

b)

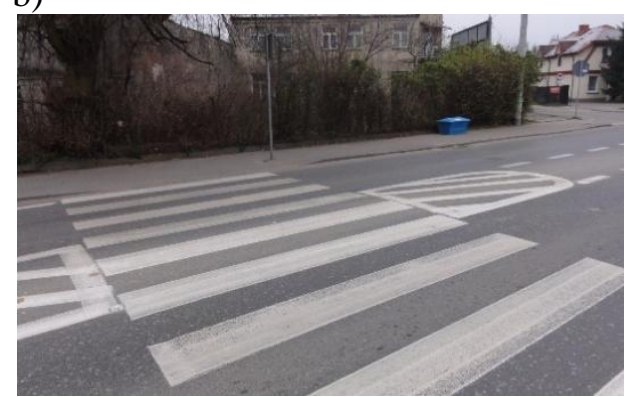

Fig. 3 Class B hazards

a)

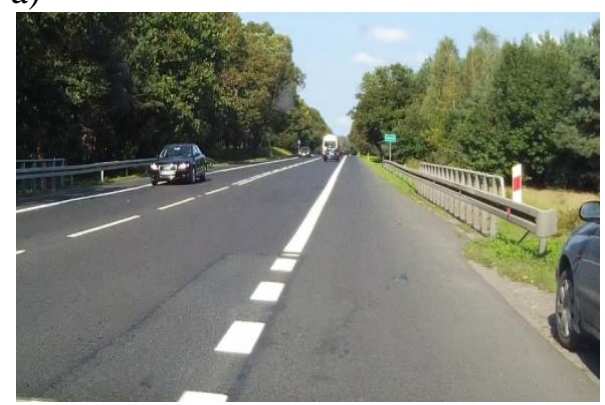

b)

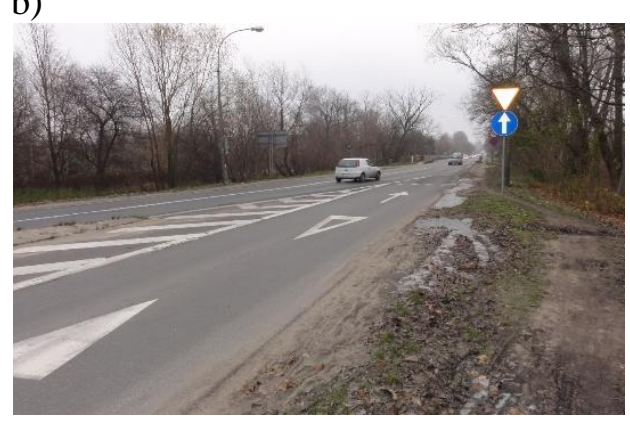

Fig. 4 Class $C$ hazards

Experience from previous road safety inspections on Polish roads and the authors' own site work was used to define the characteristics of the hazard classes:

- class A: the effect of defects on safety is low or none - acceptable level of risk, if removed, the road standard improves; if this would involve significant expenditure, no improvements will be made (except when this is part of a comprehensive section treatment), 
Road safety inspection as a tool for road safety management - the polish experience Inspekcja drogowa jako narzędzie zarzadzania bezpieczeństwem ruchu drogowego...

- class B: the effect on safety is medium - tolerated level of risk, if removed, the road standard and safety would improve substantially; if this would involve significant expenditure, temporary treatments would be required to reduce the risk of accidents,

- class C: the effect on safety is significant - unacceptable level of risk, the defects must be removed to improve safety, safety treatments must be made as soon as possible.

The same defects are ranked differently under different conditions. This can be exemplified with unprotected objects close to the roadway (such as trees, lampposts) which can be ranked as class $\mathrm{A}, \mathrm{B}$ and $\mathrm{C}$ hazards:

- built-up area with no restrictions to visibility (A),

- built-up area - restricting visibility (B),

- non-built-up area $(90 \mathrm{~km} / \mathrm{h})$, distance $0-3 \mathrm{~m}(\mathrm{C}) ; 3.1-5 \mathrm{~m}(\mathrm{~B})$; above $5.0 \mathrm{~m}-(\mathrm{A})$,

- non-built-up area $(70 \mathrm{~km} / \mathrm{h})$, distance $0-1.5 \mathrm{~m}(\mathrm{C}) ; 1.6$ - $3 \mathrm{~m}(\mathrm{~B})$, above $3.1-5 \mathrm{~m}(\mathrm{~A})$,

- there may be additional differences when the location is on a horizontal curve.

Road safety inspections should lead to specific treatments designed to remove and modify hazards or to protect against them. The improvements would mainly be designed to:

- transform the road and street network to build hierarchy thanks to additions and changes to the existing network,

- develop concepts and implement in practice "self-explanatory roads" which feature: an easily recognisable function and use, traffic segregation by users and speed, speed limits adjusted to local limits and easy to understand for motorists,

- develop concepts and implement in practice "forgiving roads", with no dangerous side obstacles and equipped with passive safety measures,

- remove errors in road infrastructure that cause accident concentration sites the so called "black spots" and sections with the highest risk of fatality,

- implement measures designed to reduce head-on crashes by separating traffic flows and enabling safe overtaking manoeuvres,

- develop pedestrian and cyclist facilities and introduce relevant maintenance standards to ensure that walking and cycling has no barriers and is safe,

- introduce new safer solutions in the infrastructure as regards junctions and road cross-sections,

- ensure a more comprehensible and traffic user friendly signage,

- implement infrastructural treatments to improve road user safety when visibility is restricted,

- implement ITS measures for road traffic enforcement and control.

\section{Modelling road safety measures to support road safety inspection}

Based on literature studies, available data and our own research, twenty five factors have been identified on national roads that represent sources of hazard and risk exposure (independent variables) [8]. 
They were divided into seven groups: length of section, road cross-section and class, road traffic, roadside, shoulders, lanes, junctions, exits. The second group representing the consequences includes dependent variables: accidents, injuries, serious injuries, fatalities. Using these independent and dependent variables road safety models can be built to support identification and ranking of road network defects.

To analyse and assess road safety with this method, two groups of safety measures were adopted. They are:

- measures of societal consequences, as primary measures used to assess the effect of a planned road on road safety,

- measures of societal risk, as auxiliary measures used to assess risk on an existing and planned road.

The calculations were made based on four safety measures: number of accidents LW, number of injuries LR, number of serious injuries LCR and number of fatalities LZ, defined as societal consequences and were then converted into measures of societal risk: accident density GW, injury density GR, serious injury density GCR, fatality density GZ and combined serious injury and fatality density GCRZ. As an example of a model of societal risk measure, accident density for single carriageways outside built-up areas was used [9]:

$$
G W_{(I N Z)}=W G W^{(I N Z) *} f_{L D} * f_{U C} * f_{P R D} * f_{S N} * f_{S K G} * f_{S K P} * f_{S P} * f_{P U S} * f_{J E 2} * f_{H P}
$$

Where:

$\boldsymbol{L} \boldsymbol{W}_{(I N Z)}-$ number of accidents (LW) on a single carriageway, dual carriageway in forecast year, (acc./year), $\boldsymbol{L}$ - length of analysed road section $(\mathrm{km}), \boldsymbol{G} \boldsymbol{W}_{(I N Z)}$ accident density $(\mathrm{GW})$ on a single carriageway, dual carriageway in forecast year (acc./km/year), $\boldsymbol{W} \boldsymbol{G} \boldsymbol{W}^{(I N Z)}$ - traffic volume impact, $\boldsymbol{f}_{\boldsymbol{L D W}}$ - road location impact by the regions LDW, taking into account the regional characteristics, $\boldsymbol{f}_{U C}-$ heavy vehicle share in traffic UC (\%), $\boldsymbol{f}_{P R D}$ - the effect of an additional lane PRD, $\boldsymbol{f}_{S N}-$ the effect of the technical condition of roadway $\mathrm{SN}, \boldsymbol{f}_{S K G}-$ the combined effect of main junction density SKG, $\boldsymbol{f}_{S K P}-$ the effect of other junctions density and public entry density ZPU, $\boldsymbol{f}_{S P}$ - technical condition of shoulder SP, $\boldsymbol{f}_{P U S}-$ the effect of a wide hard shoulder PUS, $f_{J E 2}$ - the effect of short sections with a second carriageway on single carriageway sections JE2, $f_{H P}$ - the effect of forecast horizon taking into account the level of socio-economic development and systemic solutions HP.

For the factors under analysis, the following are the observed effects on accident density $\mathrm{GW}^{(1 \mathrm{NZ})}$

- increasing - traffic volume, road class KD, road location LD, condition of shoulder SP, main junction density SKG (junctions with national roads, density of other junctions SKP and public entries ZPU,

- decreasing - share of heavy vehicles UC, condition of roadway SN, share of sections with additional lane PRD, share of sections with a second carriageway JE2. 
Road safety inspection as a tool for road safety management - the polish experience Inspekcja drogowa jako narzędzie zarzadzania bezpieczeństwem ruchu drogowego...

\section{Problems of local authority roads}

The procedures and analyses described above apply to national roads because they have implemented the tools set out in the EU Directive. The rest of Poland's road network is covered by selected tools that apply to regional roads and parts of selected cities (ranking of high-risk sections, audit of design documentation). Yet there are no road safety inspection procedures. The authors' own research shows a number of serious problems and hazards which may cause serious injury accidents. Fig. 5 gives examples of such hazards on regional roads. These are typical infrastructural faults, such as no facilities for pedestrians - pavements or safe passages, trees posing a risk to road users or poor road geometry (a - no pedestrian infrastructure, $\mathrm{b}$ - dangerous roadside, $\mathrm{c}$ - dangerous junctions).
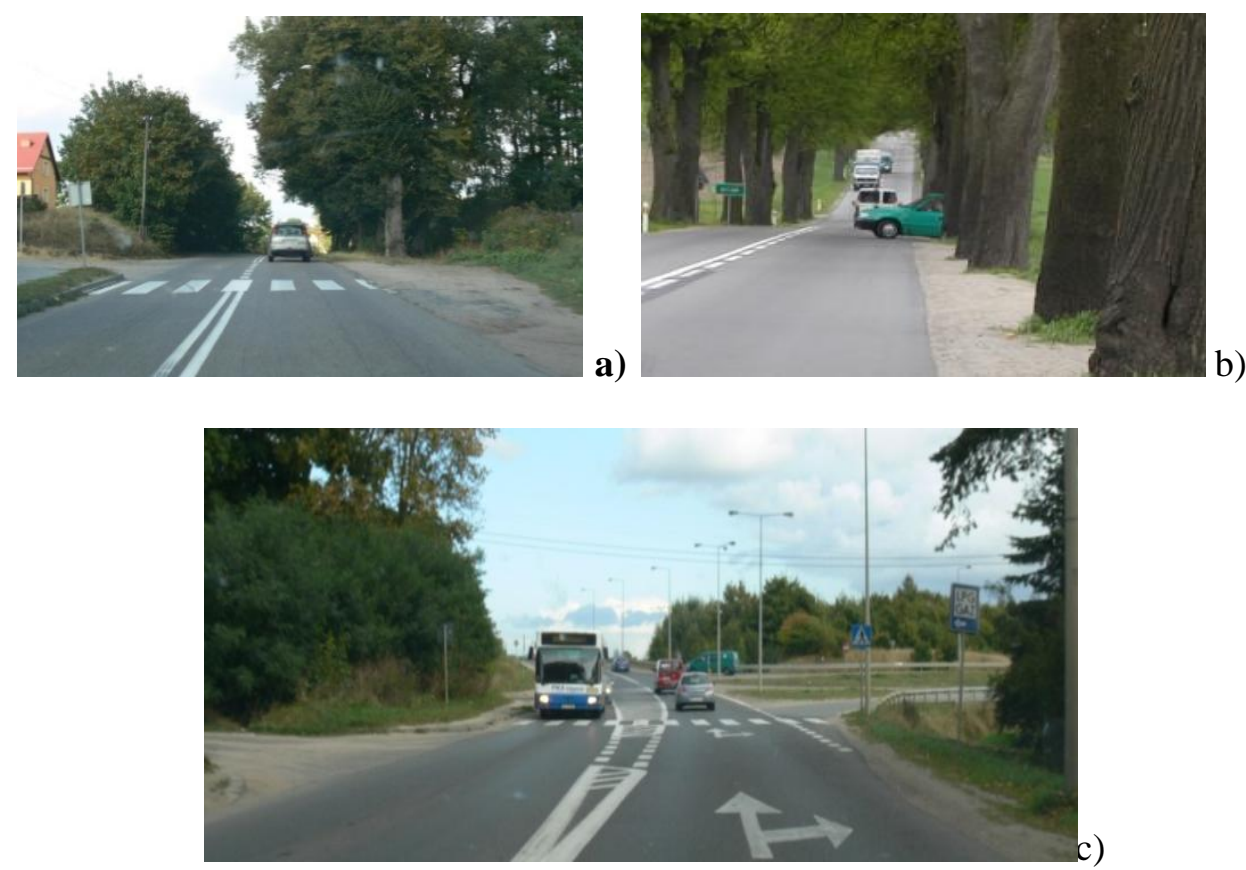

Fig. 5 Examples of hazards on regional roads

A comparison of national and local authority roads (e.g. regional roads) shows that accident types and accident sites differ between these two types of roads. As an example, hitting a tree and vehicle rollover and side crashes are clearly more frequent on local authority roads (the roadside is definitely more hazardous with greater access). As regards accident sites, accidents on horizontal curves are more frequent on local authority roads. 


\section{Conclusion}

The authors' preliminary analyses show that the effectiveness of road infrastructure safety management tools, i.e. how effective they are in reducing accident casualties, is estimated as follows: road safety impact assessment: $10-25 \%$, road safety audit (three stages combined): $5-20 \%$, infrastructure inspection (systematic): $1-20 \%$. The effectiveness increases on roads which did not have any road safety management procedures before. A well organised road safety system, equipped with the right structures and procedures can help to reduce the risk of injury or death of road users. If properly applied, road safety inspection as one of road safety management tools, can help to reduce accident casualties. Because the method presented here applies to national roads only, new methods for road safety management on local authority roads should be developed and implemented. In addition, new tools should be built to ensure that road traffic hazards are objectively ranked and road safety treatments are evaluated for their effectiveness. If implemented, new and innovative elements of automating road safety inspection procedures (data collection, defect classification, choice of the most effective remedial measures) will help to make it more efficient and consequently improve the safety of road users.

\section{References}

[1] Directive of the European Parliament and of the Council of 19 November 2008 on road infrastructure safety management 2008/96/CE (Official Journal of the European Union L.319/59)

[2] Budzyński M., Jamroz K., Kustra W., Gaca S., Michalski L., Classification of dangerous road sections on national roads - Prepared for GDDKiA, Gdansk University of Technology, Cracow University of Technology, 2013.

[3] Cafiso S., La Cava G., Montella A., Pappalardo G. Operative Procedures for Safety Inspections on Two - Lane Rural Roads, IASP, 2006 Catania, Italy

[4] Road Safety Inspection RVS 02.02.34 Bundesministerium für Verkehr, Innovation und Technologie, Österreichische Forschungsgesellschaft StraßeSchiene - Verkehr. Ausgabe - Juli 2012.

[5] EuroRAP, Road protection score (RPS) method and pilot results, 2002.

[6] Road Safety Inspection Guideline For Safety Checks of Existing Roads, World Road Association (PIARC), France 2012

[7] Jamroz K., Strategic Risk Measures in Road Traffic, J. Konbin. 13 (2010). 
Road safety inspection as a tool for road safety management - the polish experience Inspekcja drogowa jako narzędzie zarzadzania bezpieczeństwem ruchu drogowego...

[8] Jamroz K., Kustra W., Analysis of factors influencing the density of fatalities on national roads in Poland, J. Konbin. 1 (2010) 221-234.

[9] Budzyński M., Kustra W.: Hazard analysis on homogeneous sections of roads. Drogownictwo 4/2012
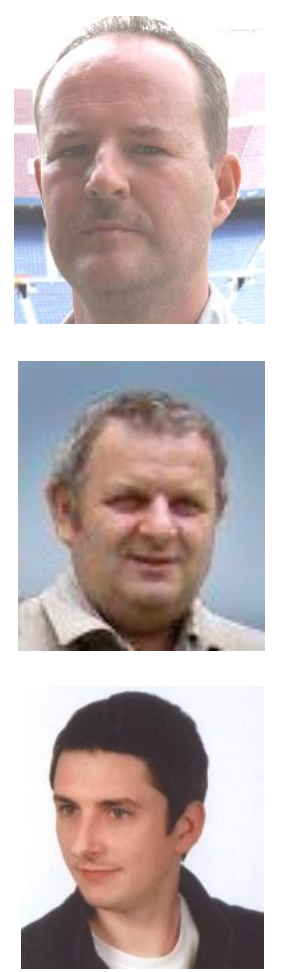

Marcin Budzyński PhD. Eng. He has been working at the Gdansk University of Technology for 22 years. Experience in the design and operation of road infrastructure with a special focus on road safety. He qualified as road safety auditor and has been teaching road safety audit courses for ten years. He organises road safety inspector courses and has trained more than 300 members of staff of the General Directorate for National Roads and Motorways (Share 60\%).

Kazimierz Jamroz PhD. Eng. He has been working at the Gdansk University of Technology for 40 years. Many years of experience in road infrastructure management and road risk management. Author of numerous scientific publications, studies in the field of road traffic engineering and transport. Conducting courses on road safety, since 10 years of the auditor's responsibility. He qualified as road safety auditor and has been teaching road safety audit courses for ten years (Share 20\%).

Wojciech Kustra PhD. Eng. He has been working at the Gdansk University of Technology for nearly 20 years. Experience in the planning and operation of road infrastructure, with particular emphasis on traffic modeling, database exploration and traffic safety analysis (Share 20\%). 


\section{INSPEKCJA DROGOWA JAKO NARZĘDZIE ZARZĄDZANIA BEZPIECZEŃSTWEM RUCHU DROGOWEGO - DOŚWIADCZENIA POLSKIE}

\section{Wstęp}

Pod względem liczby ofiar śmiertelnych wypadków drogowych, Polska ciągle jeszcze znajduje się na najgorszych miejscach w Unii Europejskiej. W 2015 roku na polskich drogach zginęło 2938 uczestników ruchu drogowego, a 39,8 tys. było rannych. Działania zawarte w krajowych i wojewódzkich programach bezpieczeństwa ruchu drogowego (brd) przyczyniają się do systematycznego zmniejszania liczby ofiar śmiertelnych w Polsce, ale uzyskiwane efekty są jeszcze dalekie od oczekiwań.

Sieć drogowa w Polsce, pomimo przekształceń, ciągle jeszcze w wielu przypadkach nie odpowiada standardom bezpieczeństwa, jednocześnie brak tych standardów rzadko jest podawany, jako przyczyna wypadków drogowych. Brak standardów bezpieczeństwa wiąże się z występowaniem mankamentów na sieci dróg, które bezpośrednio zagrażają uczestnikom ruchu drogowego lub sprzyjają popełnianym przez tych uczestników błędom. Konieczne jest identyfikowanie i eliminowanie tych mankamentów i dostosowanie istniejącej sieci drogowej do wymaganych standardów bezpieczeństwa. Mankamenty identyfikowane są na podstawie prowadzonych inspekcji drogowych. Wdrożenie ich zostało narzucone krajom członkowskim UE przez Dyrektywę 2008/96/CE [1] dotyczącą zarządzania bezpieczeństwem ruchu drogowego. Dyrektywa wskazuje cztery główne obszary działań:

- ocena wpływu na bezpieczeństwo ruchu drogowego (ocena brd),

- audyt bezpieczeństwa ruchu drogowego (audyt brd),

- klasyfikacja odcinków o dużej koncentracji wypadków (klasyfikacja odc.) oraz klasyfikacja ze względu na bezpieczeństwo sieci (klasyfikacja sieci),

- kontrola (inspekcja) bezpieczeństwa ruchu drogowego (inspekcja brd).

W roku 2013 na zlecenie GDDKiA, Politechnika Gdańska oraz Politechnika Krakowska przygotowały „Instrukcję kontroli stanu bezpieczeństwa ruchu” niezbędną do wdrożenia Dyrektywy oraz zarządzeń dyrektora GDDKiA w zakresie inspekcji brd [2]. W roku 2015 nastąpiła aktualizacja Instrukcji, po 2 latach jej wdrażania, ze względu na konieczność zwiększenia efektywności realizowanych w terenie kontroli, sporząazanych na ich podstawie raportów oraz przede wszystkim wdrażanych działań po kontrolnych. 
Road safety inspection as a tool for road safety management - the polish experience Inspekcja drogowa jako narzędzie zarzadzania bezpieczeństwem ruchu drogowego...

\section{Doświadczenia innych krajów}

Działania kontrolne prowadzone w wielu krajach na istniejącej sieci drogowej sprowadzają się głównie do identyfikacji zagrożeń oraz ich klasyfikacji. Kluczowe jest przyporządkowanie identyfikowanych zagrożeń do klasy ryzyka. Inspekcja powinna być traktowana jako interdyscyplinarna ocena, uwzględniająca wszystkie działy wiedzy związane $\mathrm{z}$ bezpieczeństwem ruchu drogowego. Dlatego uwzględniane są $\mathrm{w}$ niej nie tylko techniczne aspekty infrastruktury drogowej i pojazdów, ale także wiedza o zachowaniach uczestników ruchu drogowego wraz $\mathrm{z}$ uwarunkowaniami m.in. fizjologicznymi i psychologicznymi w ujęciu funkcjonowania systemu ,człowiek - droga - pojazd - otoczenie” [3], [4].

Wytyczne prowadzenia inspekcji drogowych są opracowane i wdrażane nie tylko w poszczególnych krajach. Zasady prowadzenia inspekcji brd zostały przedstawione przez dwie organizacje: EuroRap i PIARC. EuroRAP to Europejski Program Oceny Ryzyka na Drogach [5], a zarazem międzynarodowa organizacja pożytku publicznego. PIARC to Światowe Stowarzyszenie Drogowe zrzeszające administracje drogowe z ponad 120 państw [6].

Procedury zapisane przez obie organizacje ogólnie są zbieżne $\mathrm{z}$ zasadami opisanymi w poszczególnych krajach, jednak różnie rozłożone są poszczególne akcenty ich wdrażania. Ocena zagrożenia polega na ocenie rzeczywistego poziomu bezpieczeństwa analizowanego odcinka drogi. $\mathrm{Na}$ podstawie inspekcji brd wykonywanej w terenie ocenia się prawdopodobieństwo uwikłania w wypadek drogowy $\mathrm{z}$ ofiarami śmiertelnymi lub ciężko rannymi. Wielkość prawdopodobieństwa zależy od standardów, jakie posiada droga po procesie planowania, projektowania i budowy oraz aktualnego zarządzania ruchem.

\section{Uwarunkowania i procedury wdrażania inspekcji brd w Polsce}

Inspekcja drogi pod kątem brd jest elementem systemu zarządzania bezpieczeństwem ruchu drogowego w oparciu o zarządzanie ryzykiem [7] i należy do grupy działań i środków prewencyjnych stosowanych przez zarządy dróg. Inspekcja drogi ma na celu identyfikację zagrożeń i źródeł zagrożeń na sieci dróg, co pozwoli na wdrożenie efektywnych środków poprawy bezpieczeństwa użytkowników dróg oraz podniesienie standardów sieci drogowej.

Inspekcje sieci drogowej podzielono na 3 rodzaje - ogólna (cykliczny przejazd kontrolowanymi drogami), szczegółowa (wizja lokalna w terenie, dodatkowo obserwacje zachowań uczestników ruchu drogowego i pomiary np. widoczności) i specjalna (w porze nocnej, w rejonie robót drogowych). Wyniki inspekcji mogą służyć do aktualizowania warunków technicznych lub wytycznych projektowania oraz do wspomagania decyzji o wyborze rozwiązań naprawczych. Na rys. 1 przedstawiono schemat procedury wykonywania kontroli. 
Zidentyfikowane defekty powinny być ocenione i zakwalifikowane do trzech klas zagrożenia: klasa A - małe, klasa B - średnie, klasa C - duże. Dla poszczególnych klas defektów przyporządkowano również klasy ryzyka: duże - nieakceptowane klasa zagrożeń defektów $\mathrm{C}$, średnie - dopuszczalne warunkowo (akceptowalne pod warunkiem wykonania odpowiednich działań) - klasa zagrożeń defektów B, małe - akceptowalne, klasa zagrożeń defektów A. Na podstawie klas ryzyka należy określić reakcję na zagrożenie: natychmiastową, rozłożoną w czasie - przy zastosowaniu natychmiastowych działań tymczasowych oraz odsuniętą w czasie. Podstawą kwalifikacji powinna być ocena inspektorów (na podstawie ich wiedzy i doświadczenia) oraz obiektywne miary zagrożenia.

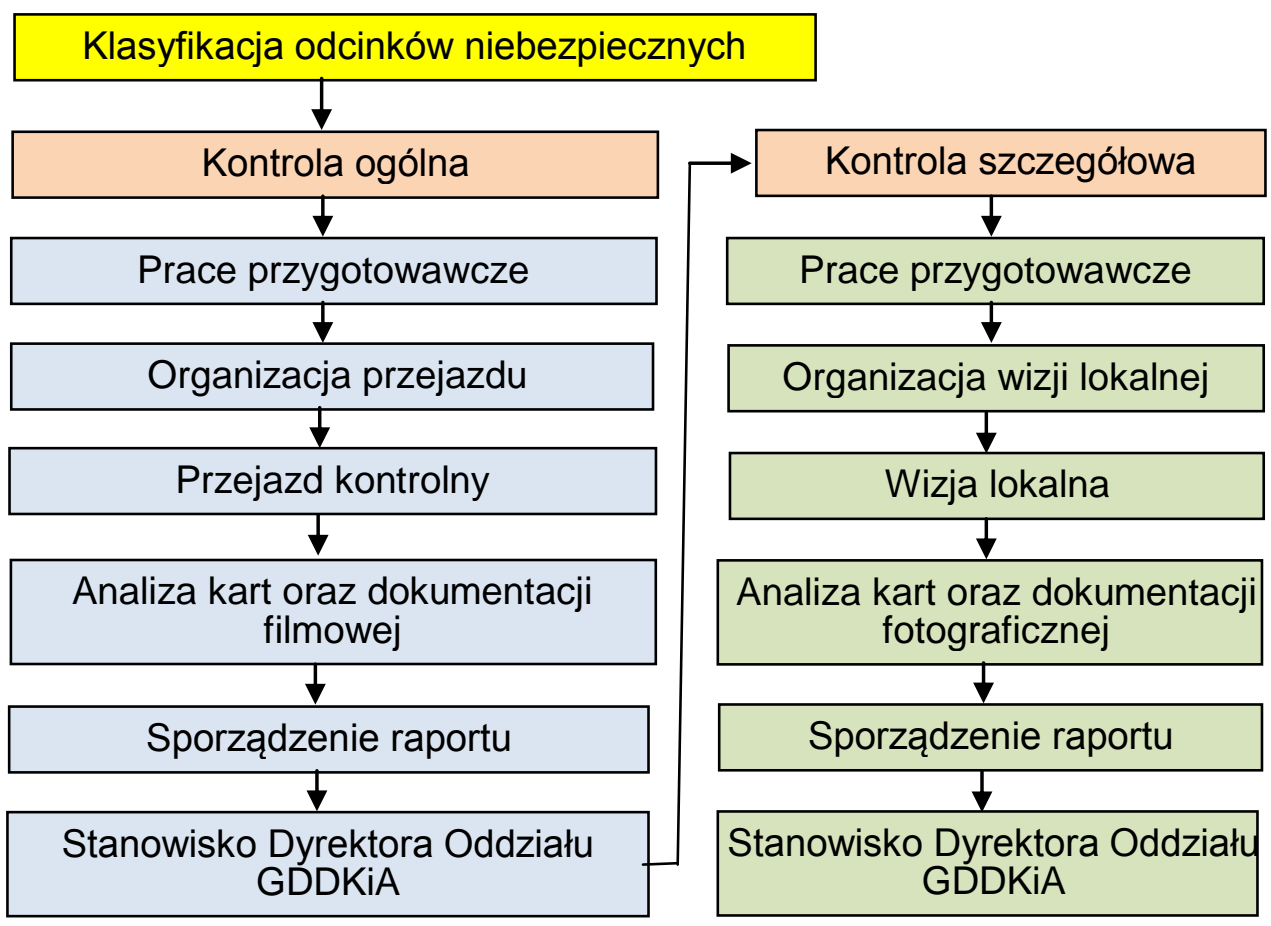

Rys. 1 Schemat procedury wykonywania kontroli brd na sieci dróg

\section{Przykłady identyfikacji i klasyfikacji zagrożeń oraz wybrane środki naprawcze}

Główne kryteria wg których klasyfikuje się identyfikowane podczas Inspekcji defekty to:

- prędkość dopuszczalna - określona przepisami lub wynikająca z lokalnych ograniczeń prędkości oraz prędkość rzeczywista (jeżeli może odbiegać znacząco od dopuszczalnej - konsekwencja np. nieprawidłowego przekroju poprzecznego), 
Road safety inspection as a tool for road safety management - the polish experience Inspekcja drogowa jako narzędzie zarzadzania bezpieczeństwem ruchu drogowego...

- rodzaj obszaru (zabudowany miejski, zabudowany - małe miejscowości, zabudowany peryferyjny miejski, niezabudowany),

- rodzaj przekroju poprzecznego (przekrój 1x2 + szerokie pobocza utwardzone na odcinkach zamiejskich to już potencjalna klasa $\mathrm{C}$, podobnie przekroje typu $1 \mathrm{x} 4$ na terenach zabudowanych, przekrój $2 \times 2$ lub $2 \times 3$ to często potencjalnie znacznie większa prędkość rzeczywista od dopuszczalnej - klasa C $\mathrm{w}$ przypadku przejść dla pieszych $\mathrm{w}$ poziomie jezdni bez sygnalizacji świetlnej),

Na rys. 2 przedstawiono przykłady zagrożeń klasy A - słup oświetleniowy zlokalizowany $\mathrm{w}$ obrębie chodnika (a), brak połączenia przejścia dla pieszych z chodnikiem (b). Na rys. 3 przedstawiono przykłady zagrożeń klasy B - brak zatoki autobusowej i zły stan techniczny pobocza (a), brak wyspy azylu w krawężnikach w obrębie przejścia dla pieszych (b). Należy podkreślić, że dla przykładu (a) brak dojścia pieszych do przystanku oraz brak wyspy azylu w obrębie przejścia dla pieszych jest potencjalnie zagrożeniem klasy C. Na rys. 4 przedstawiono przykłady zagrożeń klasy $\mathrm{C}$ - nieprawidłowe zakończenie bariery (a), geometria skrzyżowania, sposób ukształtowania wlotu podporządkowanego (b).

Na podstawie doświadczeń z już przeprowadzonych inspekcji brd na polskich drogach, w tym własnych badań terenowych autorów, określono typową charakterystykę poszczególnych klas zagrożeń:

- klasa A: wpływ defektów na bezpieczeństwo jest mały lub żaden - poziom ryzyka akceptowalny, ich usunięcie podnosi jednak standard drogi, w przypadku gdy ich usunięcie jest związane z procesem inwestycyjnym, $\mathrm{w}$ praktyce nie będą podejmowane działania (z wyjątkiem kompleksowej przebudowy odcinka),

- klasa B: ich wpływ na bezpieczeństwo jest średni - poziom ryzyka tolerowany, ich usunięcie podnosi znacząco standard drogi, zwiększa bezpieczeństwo w znacznym stopniu, w przypadku gdy ich usunięcie jest związane z procesem inwestycyjnym, konieczność podejmowania działań tymczasowych obniżających ryzyko wystąpienia wypadków,

- klasa C: ich wpływ na bezpieczeństwo jest znaczący - poziom ryzyka nieakceptowalny, ich usunięcie jest konieczne i zwiększa bezpieczeństwo w bardzo znacznym stopniu, jak najszybsze podjęcie działań naprawczych.

Przykładem zróżnicowanego klasyfikowania tych samych defektów przy różnych uwarunkowaniach może być występowanie niezabezpieczonych obiektów przy krawędzi jezdni (np. drzewa, kolumny oświetleniowe), w przypadku których mogą występować klasy A, B i C zagrożenia:

- teren zabudowany bez ograniczenia widoczności (A),

- teren zabudowany - ograniczenia widoczności (B),

- teren niezabudowany $(90 \mathrm{~km} / \mathrm{h})$ odległość $0-3 \mathrm{~m}(\mathrm{C}) ; 3,1-5 \mathrm{~m}(\mathrm{~B})$; powyżej 5,0 $\mathrm{m}-(\mathrm{A})$,

- teren niezabudowany $(70 \mathrm{~km} / \mathrm{h})$ odległość $0-1,5 \mathrm{~m}(\mathrm{C}) ; 1,6-3 \mathrm{~m}(\mathrm{~B})$, powyżej $3,1-5 \mathrm{~m}(\mathrm{~A})$, dodatkowe zróżnicowanie może wystąpić w przypadku lokalizacji w obrębie łuków poziomych. 

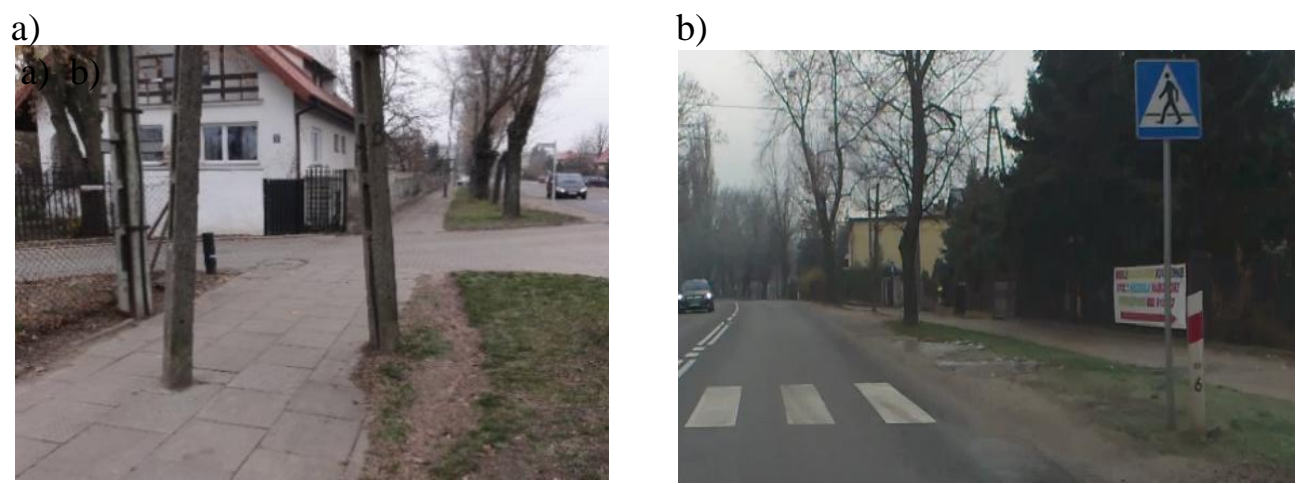

Rys. 2 Zagrożenia klasy A

a)

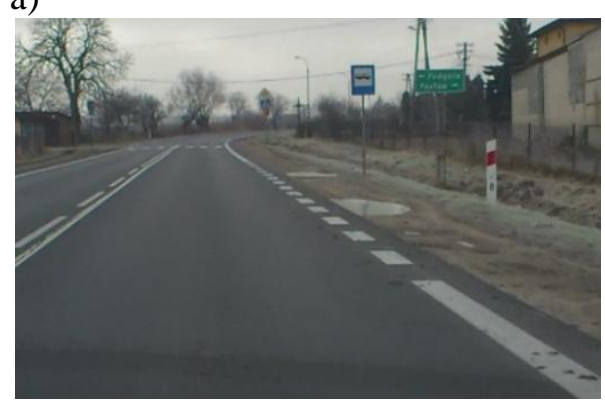

b)

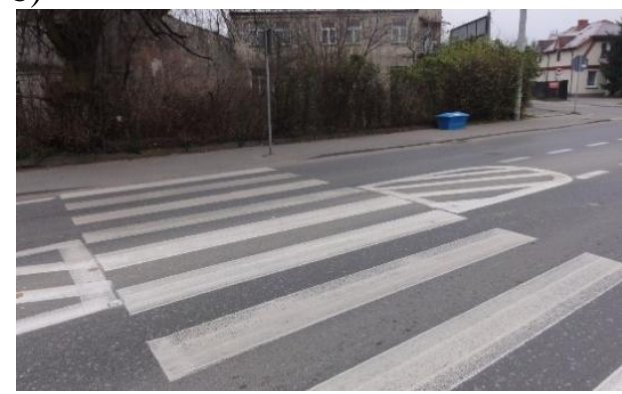

Rys. 3 Zagrożenia klasy $B$

b)

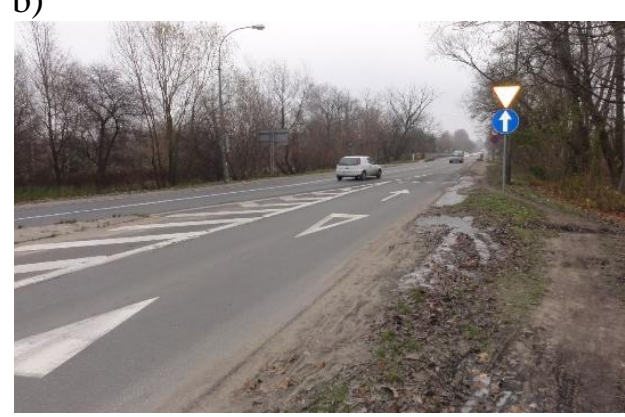

Rys. 4 Zagrożenia klasy C

Wymiernym efektem inspekcji brd powinno być wdrażanie odpowiednich środków usuwających, modyfikujących zagrożenia lub przed nimi chroniących. Główne kierunki takich działań to:

- przekształcanie sieci drogowej i ulicznej w celu uzyskania jej hierarchicznej struktury poprzez uzupełnienia i przebudowę sieci istniejącej, 
Road safety inspection as a tool for road safety management - the polish experience Inspekcja drogowa jako narzędzie zarzadzania bezpieczeństwem ruchu drogowego...

- rozwój koncepcji i praktyczne wdrożenie tzw. „dróg samo-objaśniających” charakteryzujących się: łatwo rozpoznawalną funkcją i sposobem użytkowania, segregacją ruchu z uwagi na użytkowników i prędkość, dopasowaniem limitów prędkości do lokalnych i zrozumiałych przez kierujących pojazdami lokalnych uwarunkowań,

- rozwój koncepcji i praktyczne wdrożenie tzw. „dróg wybaczających”, pozbawionych niebezpiecznych przeszkód bocznych oraz wyposażonych w środki bezpieczeństwa biernego,

- usuwanie błędów infrastruktury drogowej powodujących powstawanie miejsc koncentracji wypadków tj. tzw. „czarnych punktów” oraz odcinków o największym ryzyku wystąpienia ofiary śmiertelnej,

- wdrożenie środków zmierzających do redukcji wypadków spowodowanych zderzeniami czołowymi poprzez rozdzielanie kierunków ruchu i umożliwianie manewrów bezpiecznego wyprzedzania,

- rozwój urządzeń dla ruchu pieszego i rowerzystów oraz wprowadzenie standardów ich utrzymania, ułatwiających ruch pieszych i rowerzystów bez barier oraz z zapewnieniem jego bezpieczeństwa,

- wprowadzanie bardziej bezpiecznych, nowych rozwiązań infrastrukturalnych w odniesieniu do skrzyżowań i przekrojów poprzecznych drogi.

- zapewnienie bardziej zrozumiałego i przyjaznego uczestnikom ruchu oznakowania,

- wdrażanie środków infrastrukturalnych zwiększających bezpieczeństwo użytkowników dróg w porze ograniczonej widoczności,

- wdrażanie środków ITS w nadzorze i kierowaniu ruchem drogowym.

\section{Modelowanie miar brd, jako wsparcie dla inspekcji brd}

Na podstawie studiów literatury, dostępnych danych i własnych badań, na przykładzie odcinków dróg krajowych, zidentyfikowano 25 czynników reprezentujących źródła zagrożeń i narażenia na ryzyko (zmienne niezależne) [8]. Zostały one podzielone na 7 grup: długość odcinka, przekrój i klasa drogi, ruch drogowy, otoczenie drogi, pobocze, pasy, skrzyżowania, zjazdy. Druga grupa, reprezentująca straty, obejmowała zmienne zależne: wypadki, ofiary ranne, ofiary ciężko ranne, ofiary śmiertelne. Na podstawie wskazanych zmiennych niezależnych i zależnych możliwa jest budowa modeli brd, które wspomogą identyfikację i klasyfikację defektów sieci drogowej.

Do analizy i oceny bezpieczeństwa ruchu drogowego w niniejszej metodzie przyjęto dwie grupy miar bezpieczeństwa, są to:

- miary strat społecznych, jako miary główne, stosowane do oceny wpływu planowanej drogi na brd,

- miary ryzyka społecznego, jako miary pomocnicze, stosowane do oceny ryzyka na istniejącej i planowanej drodze. 
Obliczenia prowadzono bazując na czterech miarach bezpieczeństwa: liczbie wypadków LW, liczbie ofiar rannych LR, liczbie ofiar ciężko rannych LCR i liczbie ofiar śmiertelnych LZ, określonych jako straty społeczne, a następnie przekształcono je na miary ryzyka społecznego: gęstość wypadków GW, gęstość ofiar rannych GR, gęstość ofiar ciężko rannych GCR, gęstość ofiar śmiertelnych GZ oraz łącznie gęstość ofiar ciężko rannych i śmiertelnych GCRZ. Przykładem modelu dla miary ryzyka społecznego jest gęstość wypadków dla dróg jednojezdniowych na obszarze niezabudowanym [9]:

$$
\mathbf{G W}_{(\mathbf{I N Z})}={ }^{-} \mathrm{GW}^{(1 \mathrm{NZ})} \mathbf{f}_{\mathrm{LD}} * \mathbf{f}_{\mathrm{UC}} * \mathbf{f}_{\mathrm{PRD}} * \mathbf{f}_{\mathrm{SN}} * \mathbf{f}_{\mathrm{SKG}} * \mathbf{f}_{\mathrm{SKP}} * \mathbf{f}_{\mathrm{SP}} * \mathbf{f}_{\mathrm{PUS}} * \mathbf{f}_{\mathrm{JE} 2} * \mathbf{f}_{\mathrm{HP}}
$$

Oznaczenia dla (1):

$\boldsymbol{L} \boldsymbol{W}_{(I N Z)}$ - liczba wypadków (LW) na drodze jednojezdniowej, dwukierunkowej w danym roku prognozy, (wyp./rok), $\boldsymbol{L}$ - długość analizowanego odcinka drogi $(\mathrm{km}), \quad \boldsymbol{G} \boldsymbol{W}_{(I N Z)}$ - gęstość wypadków (GW) na drodze jednojezdniowej, dwukierunkowej dla danego roku prognozy (wyp./km/rok), $\boldsymbol{W} \boldsymbol{G} \boldsymbol{W}^{(I N Z)}$ współczynnik wpływu natężenia ruchu, $f_{L D W}$ - współczynnik wpływu lokalizacji drogi wg województw LDW, uwzględniający specyfikę danego województwa, $\boldsymbol{f}_{U C}$ - współczynnik udziału ruchu pojazdów ciężkich UC (\%), $\boldsymbol{f}_{P R D}$ - współczynnik wpływu występowania dodatkowego pasa ruchu PRD, $f_{S N}$ - współczynnik wpływu stanu technicznego nawierzchni SN, $\boldsymbol{f}_{S K G}$ - współczynnik wpływu łącznego gęstości skrzyżowań głównych SKG, $f_{S K P}$ - współczynnik wpływu gęstości skrzyżowań pozostałych oraz gęstości wjazdów publicznych ZPU, $f_{S P}-$ współczynnik stanu technicznego pobocza SP, $f_{P U S}$ - współcz. wpływu występowania pobocza utwardzonego szerokiego PUS, $f_{J E 2}$ - współczynnik wpływu występowania krótkich odcinków $\mathrm{z}$ drugą jezdnią na odcinkach jednojezdniowych JE2, $\boldsymbol{f}_{H P}$ - współczynnik wpływu horyzontu prognozy, uwzględniający poziom rozwoju społeczno-gospodarczego kraju i podejmowanych działań systemowych HP.

Dla analizowanych czynników można zaobserwować następujące wpływy na gęstość wypadków $\mathrm{GW}^{(1 \mathrm{NZ})}$ :

- rosnący - natężenie ruchu, klasa drogi KD, lokalizacja drogi LD, stan pobocza SP, gęstość skrzyżowań głównych SKG (z drogami krajowymi, gęstość skrzyżowań pozostałych SKP i wjazdów publicznych ZPU,

- malejący - udział pojazdów ciężkich UC, stan nawierzchni SN, udział odcinków z dodatkowym pasem ruchu PRD, udział odcinków z drugą jezdnią JE2.

\section{Problemy dróg samorządowych}

Powyższe procedury i analizy dotyczą dróg krajowych dla których wdrożono narzędzia zawarte w Dyrektywie UE. Dla pozostałej sieci drogowej w Polsce, wybrane narzędzia są stosowane dla dróg wojewódzkich oraz w wybranych miastach częściowo (klasyfikacja odcinków niebezpiecznych, audyt dokumentacji projektowej) ale brak jest procedur inspekcji brd. 
Road safety inspection as a tool for road safety management - the polish experience Inspekcja drogowa jako narzędzie zarzadzania bezpieczeństwem ruchu drogowego...

Badania własne autorów wskazują na bardzo poważne problemy i liczne zagrożenia, które mogą być przyczyną wypadków drogowych o dużej ciężkości. Na rys. 5 przedstawiono przykłady takich zagrożeń występujących na drogach wojewódzkich.

Są to typowe mankamenty infrastruktury, takie jak brak odpowiednich urządzeń dla ruchu pieszego - chodniki lub zabezpieczenie przejść dla pieszych, drzewa stanowiące zagrożenie dla użytkowników dróg czy nieprawidłowa geometria skrzyżowań (a - brak infrastruktury dla pieszych, b - niebezpieczne otoczenie, c - niebezpieczne skrzyżowania).
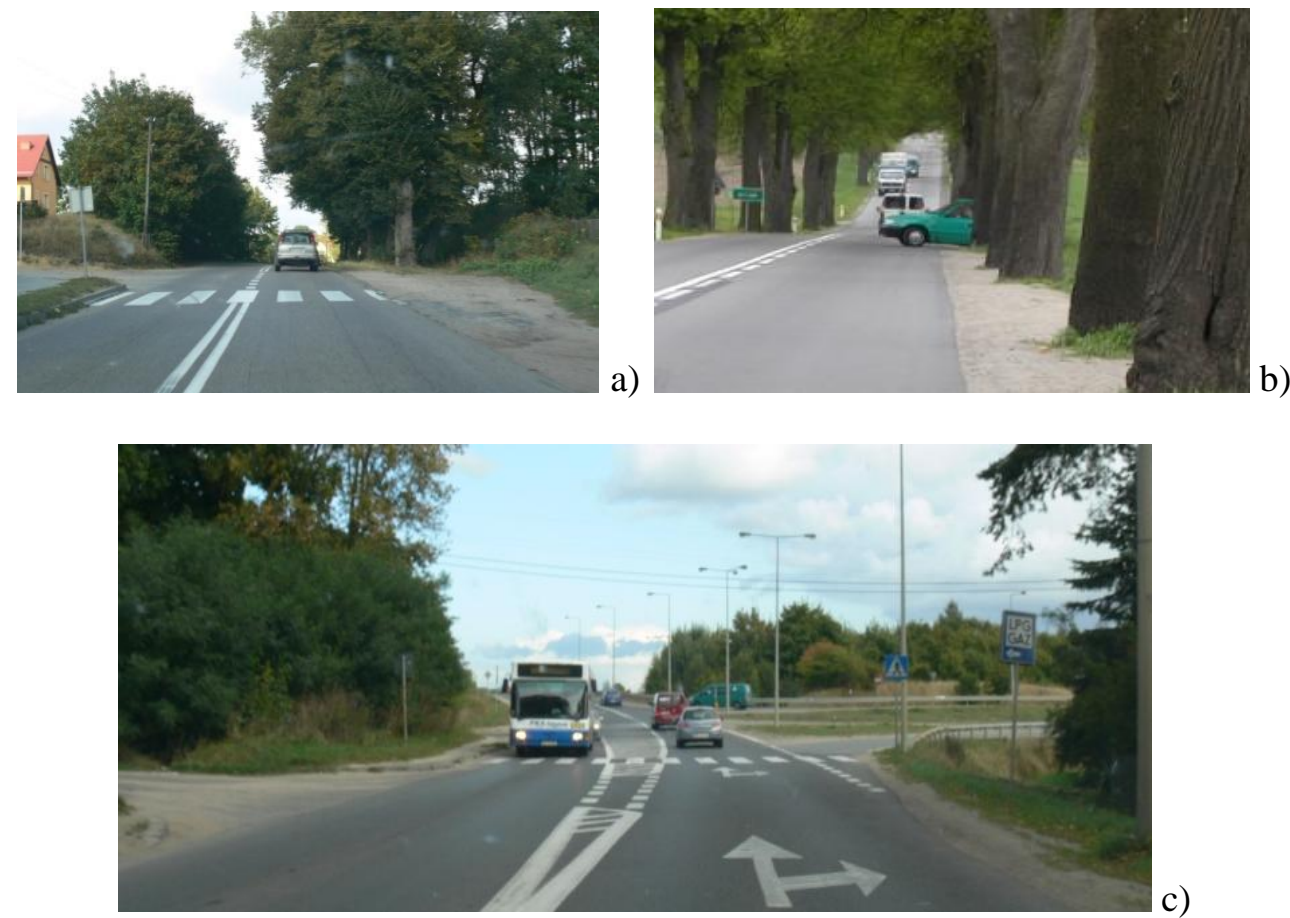

Rys. 5 Przykłady zagrożeń na drogach wojewódzkich

Porównując drogi krajowe i samorządowe (np. wojewódzkie), można wyróżnić zróżnicowanie struktury rodzajów wypadków oraz struktury lokalizacji w stosunku do dróg krajowych. Dotyczy to przede wszystkim zdecydowanie większego udziału najechania na drzewo i wywrócenia się pojazdu oraz zderzeń bocznych na drogach samorządowych (otoczenie tych dróg stanowi większe zagrożenie, a także występuje tam większa dostępność). W przypadku lokalizacji wypadków, większy jest udział na drogach samorządowych wypadków na łukach poziomych. 


\section{Podsumowanie}

Z wstępnych analiz wykonanych przez autorów wynika, że skuteczność wprowadzania poszczególnych narzędzi zarządzania bezpieczeństwem infrastruktury drogowej w postaci zmniejszenia liczby ofiar wypadków, wynosi szacunkowo: ocena wpływu na brd: $10-25 \%$, audyt brd (łącznie wszystkie etapy): $5-20 \%$, kontrola infrastruktury (systematyczna): $1-20 \%$. Wyższe wartości liczbowe skuteczności uzyskuje się na drogach, dla których nie były wykonywane procedury zarządzania BRD na wcześniejszych etapach.

Dobrze zorganizowany system bezpieczeństwa ruchu drogowego, wyposażony w odpowiednie struktury i procedury może przyczynić się do zwiększenia ochrony zdrowia $\mathrm{i}$ życia $\mathrm{w}$ ruchu drogowym. Inspekcja brd, jaki jedno $\mathrm{z}$ narzędzi zarządzania bezpieczeństwem, dobrze zastosowana, może przyczynić się do zmniejszenia liczby ofiar wypadków drogowych. Przedstawiona metoda dotyczą tylko dróg krajowych, w związku z tym należy opracować i wdrażać elementy zarządzania bezpieczeństwem na sieci dróg samorządowych. Konieczne jest również rozwijanie narzędzi pozwalających na obiektywną klasyfikację zagrożeń w ruchu drogowym oraz ocenę efektywności stosowanych rozwiązań poprawiających bezpieczeństwo ruchu drogowego. Wdrożenie innowacyjnych elementów automatyzacji wybranych procedur do procesu inspekcji brd (zbieranie danych, klasyfikacja defektów, wybór najbardziej skutecznych środków naprawczych) pozwoli na efektywniejsze jej przeprowadzanie, co przyczyni się do poprawy bezpieczeństwa użytkowników dróg.

\section{Literatura}

[1] Dyrektywa Parlamentu Europejskiego i Rady z 19 listopada 2008 roku w sprawie zarządzania bezpieczeństwem infrastruktury drogowej 2008/96/WE (Dz.U. UE L.319/59)

[2] Budzyński M., Jamroz K., Kustra W., Gaca S., Michalski L., Instrukcja klasyfikacji odcinków niebezpiecznych na drogach krajowych - Opracowanie na zlecenie GDDKiA, Politechnika Gdańska, Politechnika Krakowska, 2013.

[3] Cafiso S., La Cava G., Montella A., Pappalardo G. Operative Procedures for Safety Inspections on Two - Lane Rural Roads, IASP, 2006 Catania, Italy

[4] Road Safety Inspection RVS 02.02.34 Bundesministerium für Verkehr, Innovation und Technologie, Österreichische Forschungsgesellschaft StraßeSchiene - Verkehr. Ausgabe - Juli 2012.

[5] EuroRAP, Road protection score (RPS) method and pilot results, 2002.

[6] Road Safety Inspection Guideline For Safety Checks of Existing Roads, World Road Association (PIARC), France 2012

[7] Jamroz K., Strategic Risk Measures in Road Traffic, J. Konbin. 13 (2010). 
Road safety inspection as a tool for road safety management - the polish experience Inspekcja drogowa jako narzędzie zarzadzania bezpieczeństwem ruchu drogowego...

[8] Jamroz K., Kustra W., Analysis of factors influencing the density of fatalities on national roads in Poland, J. Konbin. 1 (2010) 221-234.

[9] Budzyński M., Kustra W.: Analiza zagrożeń na jednorodnych odcinkach dróg. Drogownictwo 4/2012

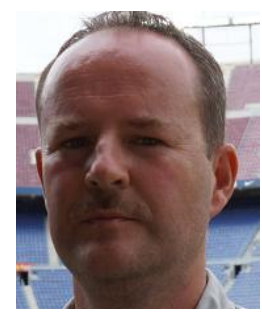

Dr inż. Marcin Budzyński od 22 lat praca na Politechnice Gdańskiej. Doświadczenie $w$ zakresie projektowania $i$ eksploatowania infrastruktury drogowej, ze szczególnym uwzględnieniem bezpieczeństwa ruchu drogowego. Uprawnienia audytora brd, od 10 lat udziat $w$ prowadzeniu kursów na audytora brd. Organizacja kursów na inspektorów brd i przeszkolenie ponad 300 osób z kadry GDDKiA (Udziat 60\%).

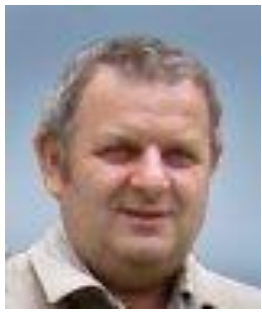

Dr hab. inz. Kazimierz Jamroz, prof. PG od 40 lat praca na Politechnice Gdańskiej. Dlugoletnie doświadczenie w zakresie zarzadzania infrastruktura drogowa oraz ryzykiem $w$ ruchu drogowym. Autor licznych publikacji naukowych, opracowań $z$ zakresu inżynierii ruchu drogowego oraz studiów transportowych. Prowadzenie kursów dotyczacych bezpieczeństwa ruchu drogowego, od 10 lat uprawnienia audytora brd (Udziat 20\%).

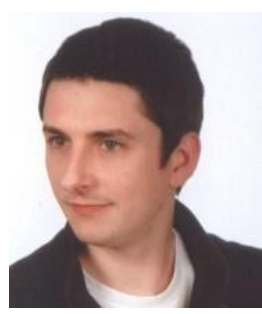

Dr in:. Wojciech Kustra od blisko 20 lat praca na Politechnice Gdańskiej. Doświadczenie w zakresie planowania $i$ eksploatowania infrastruktury drogowej, ze szczególnym uwzględnieniem modelowania ruchu drogowego, eksploracji baz danych oraz analiz bezpieczeństwa ruchu drogowego (Udziat 20\%). 